\title{
URGENSI PEMBENTUKAN BADAN PERADILAN KHUSUS DALAM PENYELESAIAN SENGKETA HASIL PILKADA LANGSUNG
}

\author{
Yonata Harefa', Haposan Siallagan ${ }^{2}$, Hisar Siregar ${ }^{3}$ \\ ${ }^{123}$ Program Studi Magister Hukum \\ Program Pascasarjana Universitas HKBP Nommensen, Medan-Sumatera Utara-Indonesia \\ e-mail: yonataharefa8o@gmail.com
}

\begin{abstract}
In accordance with the decision of the Constitutional Court Number 97 / PUU-XI / 2013, the Constitutional Court is no longer authorized to resolve disputes on direct election results, because the provisions of Article 236C of Law Number 12 Year 2008 NRI are against the Constitution of 1945. Article 157 paragraph (1) Law No. 8 Year 2015 determines that the dispute settlement on direct election results become the authority of specialized judiciary. But before a specialized judiciary is formed, then the Constitutional Court is authorized to resolve disputes on direct election results. The authority of the Constitutional Court is the constitutional authority to fulfill temporary legal vacuum (rechtvakum). Therefore legislators should immediately establish a specialized judiciary which has the authority to resolve the disputes on direct election results.
\end{abstract}

Keywords: Direct Election, Authority, Constitutional Court, Specialized Judiciary

\begin{abstract}
Abstrak
Sesuai dengan putusan MK Nomor 97/PUU-XI/2013, MK tidak lagi berwenang untuk menyelesaikan sengketa hasil Pilkada langsung, karena ketentuan Pasal 236C Undang-Undang Nomor 12 Tahun 2008 bertentangan dengan UUD NRI Tahun 1945. Pasal 157 ayat (1) UndangUndang Nomor 8 Tahun2015 menentukan bahwa penyelesaian sengketa hasil Pilkada langsung menjadi kewenangan badan peradilan khusus. Namun sebelum badan peradilan khusus tersebut dibentuk, maka MK masih berwenang untuk menyelesaikan sengketa hasil Pilkada langsung. Kewenangan MK tersebut adalah kewenangan konstitusional yang bersifat sementara untuk mengisis kekosongan hukum (rechtvakum). Karenanya pembentuk undangundang harus segera membentuk badan peradilan khusus yang mempunyai kewenangan untuk menyelesaikan sengketa hasil Pilkada langsung.
\end{abstract}

Kata kunci: Pilkada langsung, Kewenangan, Mahkamah Konstitusi, badan peradilan khusus.

\section{A. Pendahuluan}

Pasal 1 ayat (2) Undang-Undang Dasar Negara Republik Indonesia Tahun 1945 (UUD NRI Tahun 1945 menentukan bahwa: "Kedaulatan berada di tangan rakyat dan dilaksanakan menurut Undang-Undang Dasar”. Ketentuan tersebut memberikan landasan yang sangat kuat bahwa Indonesia merupakan negara demokrasi konstitusional, karenanya partisipasi rakyat di dalam pelaksanaan pemerintahan menjadi persyaratan utama, khususnya dalam pengisian jabatan- jabatan publik. Ketentuan tersebut juga secara eksplisit memberikan hak kepada rakyat untuk menentukan dan memilih pemimpinnya. Terkait dengan hal tersebut, Pasal 25 huruf b International Covenant on Civil and Political Rights (ICCPR) menentukan bahwa "Setiap warga negara harus mempunyai hak dan kesempatan, tanpa pembedaan dan tanpa pembatasan yang tidak layak, untuk memilih dan dipilih pada pemilihan umum berkala yang 
http://ejournal.uhn.ac.id/index.php/opinion

murni, dan dengan hak pilih yang universal dan sama, serta dilakukan melalui pemungutan suara secara rahasia untuk menjamin kebebasan menyatakan keinginan dari para pemilih“.

Dalam rangka memberikan daulat kepada rakyat, sistem ketetanegaraan Indonesia mengenal sistem pemilihan secara langsung sebagaimana ditentukan dalam Pasal 22E UUD NRI Tahun 1945. Pemilihan langsung tersebut merupakan manifestasi dari adanya kedaulatan yang dimiliki oleh rakyat. Terkait denganhal tersebut, Miriam Budiarjo ${ }^{1}$ menyatakan bahwa pemilihan umum adalah merupakan conditio sine quanon bagi suatu negara demokrasi modern, ${ }^{2}$ dimana melalui pemilihan umum warga negara menyerahkan sementara hak politiknya yakni hak berdaulat untuk turut serta menjalankan negara. Senada dengan hal tersebut, Dahlan Thaib menyatakan juga bahwa: ${ }^{3}$ "Pelaksanaan kedaulatan rakyat tidak dapat dilepaskan dari pemilihan umum karena pemilihan umum merupakan konsekuensi logis dianutnya prinsip kedaulatan rakyat (demokrasi) dalam kehidupan berbangsa dan bernegara. Prinsip dasar kehidupan kenegaraan yang demokratis adalah setiap warga negara berhak ikut aktif dalam proses politik".

Pasca reformasi, pelaksanaan kedaulatan rakyat (demokrasi) tidak hanya dimanifestasi dalam pemilihan umum sebagaimana ditentukan dalam Pasal 22E UUD NRI Tahun 1945. Namun, demokrasi telah dimanifestasi dalam kehidupan politik lokal melalui pendesentralisasian ${ }^{4}$ politik kepada daerah-daerah otonom. Salah satu isi kebijakan dari desentralisasi politik tersebut adalah adanya pemilihan secara demokratis terhadap jabatan Gubernur, Bupati dan Walikota. Terkait dengan hal tersebut, Pasal 18 ayat (4) UUD NRI Tahun 1945 menentukan bahwa "Gubernur, Bupati, dan Walikota masing-masing sebagai kepala pemerintah daerah provinsi, kabupaten dan kota dipilih secara demokratis". Ketentuan mengenai dipilih secara demokratis tersebut, kemudian dimanifestasi dengan adanya pengaturan mengenai Pilkada langsung yang berfungsi sarana bagi rakyat untuk berpartisipasi di dalam pelaksanaan pemerintahan daerah. Pilkada langsung tersebut merupakan suatu keniscayaan demokrasi sebagai manifestasi dari daulat rakyat. ${ }^{5}$

Dalam pelaksanaan Pilkada langsung tersebut tidak tertutup kemungkinan akan menimbulkan sengketa, yang salah satu bentuknya adalah sengketa hasil Pilkada langsung. Sengketa hasil Pilkada langsung tersebut harus diselesaikan dengan tata cara yang sesuai dengan hukum (due process of law) termasuk lembaga yang berwenang. Terkait dengan hal tersebut, beberapa peraturan perundang- undangan yang terkait dengan hal tersebut memiliki politik hukum (legal policy) yang berbeda-beda.

Di dalam ketentuan Pasal 106 Undang-Undang Nomor 32 Tahun 2004 tentang Pemerintahan Daerah, memberikan kewenangan kepada Mahkamah Agung, yang kemudian berdasarkan Pasal 236C Undang-Undang Nomor 12 Th 2008 tentang Perubahan Kedua Atas Undang-Undang Nomor 32 Tahun 2004 tentang Pemerintahan Daerah menjadi kewenangan Mahkamah Konstitusi. Namun demikian, berdasarkan Putusan Mahkamah Konstitusi Nomor 97/PUU-XI/2013, Pasal 236C Undang-Undang Nomor 12 Tahun 2008 dinyatakan bertentangan

\footnotetext{
Miriam Budiarjo, Hak Asasi Manusia Dalam Dimensi Global, (Jakarta: Jurnal Ilmu Politik, No. 10, 199o), hlm. 37 Janpatar Simamora. "Perlindungan Hak Memilih Sebagai Hak Konstitusional Warga Negara." Jurnal Yudisial, Vol. 6, No. 2 (2013): 123-142.

3 Dahlan Thaib, Implementasi Sistem Ketatanegaraan Menurut UUD 1945, (Yogyakarta: Liberty, 1993), hlm. 94 4 Menurut United Nation Devolopment Programe, desentralisasi adalah "The transfer of responsibility for planning, management, and resources raising and allocation from the central government and its agencies; (a) field units of central government ministries or agencies; (b) subordinate units or levels of government; semi autonomous public authorities or corporations; (d) area wide, regional or functional authorities; or (e) nongovernmental, private, or voluntary organization.”. Baca: M. Mas'ud Said, Arah Baru Otonomi Daerah di Indonesia. (Malang: UMM Press, 2005) hlm. 74-75

${ }^{5}$ Janpatar Simamora. "Tafsir Makna Negara Hukum dalam Perspektif Undang-Undang Dasar Negara Republik Indonesia Tahun 1945." Jurnal Dinamika Hukum 14, No. 3 (2014): 547-561.
} 
dengan UUD NRI Tahun 1945, sehingga MK tidak berwenang untuk menyelesaikan sengketa hasil Pilkada langsung.

Sehubungan dengan hal itu, Pasal 157 Undang-Undang Nomor 1 Tahun 2015 tentang Penetapan Peraturan Pemerintah Pengganti Undang-Undang Nomor 1 Tahun 2014 tentang Pemilihan Gubernur, Bupati dan Walikota (Undang-Undang Nomor 1 Tahun 2015) memberikan kewenangan kepada Pengadilan Tinggi (PT) yang ditunjuk oleh Mahkamah Agung. Kemudian ketentuan tersebut, diubah kembali dengan Undang-Undang Nomor 8 Tahun 2015 tentang Perubahan Atas Undang-Undang Nomor 1 Tahun 2015 tentang Penetapan Peraturan Pemerintah Pengganti Undang-Undang Nomor 1 Tahun 2014 tentang Pemilihan Gubernur, Bupati dan Walikota, di dalam ketentuan Pasal 157 menentukan bahwa yang berwenang adalah badan peradilan khusus. Namun sebelum terbentuk badan peradilan khusus tersebut, Pasal 157 ayat (3) Undang-Undang Nomor 8 Tahun 2015 menentukan bahwa penyelesaian sengketa hasil Pilkada langsung diselesaikan kembali oleh Mahkamah Konstitusi.

Perubahan-perubahan lembaga yang berwenang dalam menyelesaikan sengketa hasil Pilkada langsung tersebut tidak memberikan kepastian hukum. Pembentukan badan peradilan khusus juga tidak memberikan kepastian hukum, karena tidak langsung dibentuk dalam Undang-Undang Nomor 8 Tahun 2015. Bahkan ketentuan Pasal 157 ayat (3) Undang-Undang Nomor 8 Tahun 2015 tidak memberikan solusi hukum yang komprehensif, karena menunjuk kembali Mahkamah Konstitusi sebagai lembaga yang berwenang. Padahal Mahkamah Konstitusi melalui putusannya telah menyatakan dirinya tidak berwenang, karena kewenangan tersebut tidak diatur dalam Pasal 24C ayat (1) UUD NRI Tahun 1945.

\section{B. Metode Penelitian}

Dalam penelitian ini, pendekatan-pendekatan yang digunakan dalam penelitian hukum adalah pendekatan undang-undang (statute approach), pendekatan kasus (case approach), pendekatan historis (historical approach), pendekatan komparatif (comparative approach), dan pendekatan konseptual (conceptual approach). ${ }^{6}$ Dalam penelitian ini seluruh pendekatan tersebut akan digunakan sesuai dengan permasalahan yang diteliti. Dengan demikian terbuka kemungkinan untuk menggunakan seluruh atau sebagian pendekatan tersebut sesuai dengan kebutuhan. Data untuk penelitian ini dikumpulkan melalui penelitian kepustakaan (library reasearch). Bahan kepustakaan akan meliputi bahan hukum primer ${ }^{7}$ berupa Undang-Undang Dasar Negara Republik Indonesia Tahun 1945 dan berbagai Undang-Undang yang berkaitan dengan Pemilihan Umum di Indonesia. Bahan hukum sekunder berupa bahan yang memberikan kejelasan terhadap bahan hukum primer berupa hasil penelitian, makalah, artikel, surat kabar, dan lain-lain. Sedangkan bahan hukum tersier, yaitu sumber yang memberikan petunjuk dan penjelasan terhadap bahan hukum sekunder seperti kamus dan ensiklopedia.

\section{Pembahasan}

\section{Penyelesaian Sengketa Hasil Pilkada Langsung}

Perubahan UUD NRI Tahun 1945 telah berimplikasi terhadap perubahan sistem ketatanegaraan Republik Indonesia. Salah satu perubahan mendasar tersebut adalah adanya penguatan atas pelaksanaan otonomi daerah. Hal tersebut diatur dalam Pasal 18 UUD NRI Tahun 1945, yang memberikan kewenangan otonomi yang seluas-luasnya kepada daerah otonom. Otonomi tersebut memberikan kewenangan kepada daerah otonom untuk mengatur

6 Peter Mahmud Marzuki, Penelitian Hukum, hal.93.

${ }^{7}$ Janpatar Simamora, "Menyongsong Rezim Pemilu Serentak", Jurnal Rechtsvinding, BPHN Jakarta, Vol. 3 No 1 (2014), hlm. 05. 
Jurnal Magister Hukum Program Pascasarjana Universitas HKBP Nommensen

Volume o1 Nomor o1 Juli 2020 Halaman. 139-152

e-ISSN: 2723-164X p-ISSN: 2722-9858

http://ejournal.uhn.ac.id/index.php/opinion

(regelendaad) dan mengurus (bestuurdaad) urusan pemerintahan yang menjadi kewengannya. Otonomi merupakan the right of self government. ${ }^{8}$ Dengan kata lain bahwa otonomi merupakan pendesentralisasian kewenangan pemerintahan oleh pusat kepada daerah otonom. ${ }^{9}$ Dengan adanya otonomi, daerah-daerah otonom diberikan kebebasan dan kemandirian untuk mengurus dan mengatur semua urusan pemerintahan yang menjadi kewenangannya. ${ }^{10}$

Pemberian otonomi tersebut tidak hanya terbatas pada pemberian urusan pemerintahan, namun juga harus disertai dengan adanya pendesentralisasian kehidupan politik lokal. Hal tersebut diwujudkan dalam Pilkada langsung dalam pengisian jabatan Gubernur, Bupati dan Walikota. Hal tersebut secara eksplisit ditentukan dalam Pasal 18 ayat (4) UUD NRI Tahun 1945 yang menentukan bahwa "Gubernur, Bupati, dan Walikota masing-masing sebagai kepala pemerintah daerah provinsi, kabupaten dan kota dipilih secara demokratis. Frase "dipilih secara demokratis" tersebut secara umum dapat diartikan bahwa pemilihan kepala daerah, baik gubernur, bupati maupun walikota harus dipilih dengan cara melibatkan partisipasi masyarakat.

Partisipasi masyarakat tersebut dapat dilakukan, baik secara langsung melalui Pilkada langsung maupun secara perwakilan melalu Dewan Perwakilan Rakyat Daerah. Esensi dari frase "dipilih secara demokratis" tersebut adalah tertelak pada proses pengisian jabatan kepala daerah yang harus dilakukan secara demokratis. Frase "dipilih secara demokratis" tersebut tidak menunjuk pada model, apakah langsung ataupun perwakilan. Namun demikian, Taufiqurrahman Syahuri menyatakan bahwa frase "dipilih secara demokratis" hanya dapat dimaknai dengan pemilihan secara langsung."

Atas dasar Pasal 18 ayat (4) UUD NRI Tahun 1945 di atas, Pasal 2 ayat (1) UndangUndang Nomor 1 Tahun 2015 menentukan bahwa "Pemilihan dilaksanakan secara demokratis berdasarkan asas langsung, umum, bebas, rahasia, jujur, dan adil”. Dari ketentuan tersebut, maka Gubernur, Bupati atau Walikota dipilih secara langsung oleh rakyat. Pilkada langsung tersebut merupakan perwujudan daulat rakyat untuk ikut serta di dalam pelaksanaan pemerintahan daerah. Pilkada langsung tersebut merupakan keniscayaan demokrasi yang harus dilaksanakan.

Dari aspek hak warga negara, Pilkada langsung merupakan wujud dari adanya pemenuhan hak warga negara. Untuk mewujudkan hak tersebut, maka Pilkada langsung memegang peranan yang sangat penting dalam mewujudkan pemerintahan daerah yang demokratis. Pemerintahan daerah yang demokratis tersebut ditandai dengan adanya partisipasi masyarakat di dalam pengisian jabatan kepala daerah. Terkait dengan hal tersebut, Amien Rais menyatakan bahwa ciri utama negara demokratis adalah partisipasi masyarakat dalam pembuatan keputusan bernegara. ${ }^{12}$ Bahkan substansi dari sistem demokratis adalah adanya peran serta atau partisipasi aktif warga negara dalam proses pengambilan keputusan

\footnotetext{
8 Hanry Campbell Black, Black Law Dictionary, (USA: ST. Paul Mint. West Pu-blishing Co., 1979), hlm. 154

9 The Liang Gie, Pertumbuhan Pemerintahan Daerah di Negara Republik Indonesia, (Yogyakarta: Liberty, 1967), hlm. 109

${ }^{10}$ Philipus M. Hadjon, Sistem Pembagian Kekuasaan Negara (Analisis Hukum Tata Negara), (Surabaya: Fakultas Hukum Universitas Airlangga), hlm. 6

${ }^{11}$ Taufiqqurahman Syahuri dalam Yusak Elisa Reba, Kompetensi Mahkamah Konstitusi Dalam Menyelesaikan Sengketa Hasil Pemilihan Umum Kepala Daerah, (Papua: Jurnal Konstitusi, PSK-FH, Uncen, Vol. 1 No. 1 Juni 2009), hlm. 66

${ }^{12}$ Amien Rais dalam Agus Wijayanto Nugroho, Kewenangan Mahkamah Konstitusi Dalam Sengketa Pemilu Legislatif (Sebuah Pembelajaran Dalam Mewujudkan dan Menjaga Kedaulatan Rakyat), (Banjarmasin: Jurnal Konstitusi, PKK-FH, Lambung Mangkurat, Vol. II No. 1 Juni 2009), hlm. 65
} 
bernegara. ${ }^{13}$ Oleh karena itu, Pilkada langsung harus dilaksanakan sesuai dengan prinsipprinsip demokrasi dan good governance dengan bertitik tolak pada pelaksanaan Pilkada langsung yang berkeadilan, terbuka dan dapat memberikan kepastian hukum. Bahkan lebih dari itu, Pilkada dilaksanakan dengan prinsip langsung, umum, bebas, rahasia, jujur dan adil.

Pilkada langsung dan demokrasi tidak dapat dipisahkan satu dengan yang lainnya. Artinya bahwa Pilkada langsung harus diwujudkan dengan prinsip- prinsip demokrasi, sedangkan demokrasi diwujudkan melalui Pilkada langsung. Karenanya, Robert A Dahl menyatakan bahwa: ${ }^{14}$

a. Adanya prinsip hak yang sama dan tidak diperbedakan antara rakyat yang satu dengan yang lainnya;

b. Adanya partisipasi efektif yang menunjukkan adanya proses dan kesempatan yang sama bagi rakyat untuk mengekspresikan prefensinya dalam keputusan-keputusan yang diambil;

c. Adanya pengertian yang menunjukkan bahwa rakyat mengerti dan paham terhadap keputusan-keputusan yang diambil negara, tidak terkecuali birokrasi;

d. Adanya kontrol akhir yang diagendakan oleh rakyat, yang menunjukkan bahwa rakyat mempunyai kesempatan istimewa untuk membuat keputusan dan dilakukan melalui proses politik yang dapat diterima dan memuaskan berbagai pihak;

e. Adanya inclusiveness yakni suatu pertanda yang menunjukkan bahwa yang berdaulat adalah seluruh rakyat.

Walaupun Pilkada didasarkan pada prinsip langsung, umum, bebas, rahasia, jujur dan adil, namun dalam pelaksanaannya sangat berpotensi untuk menimbulkan pelanggaran dan sengketa. Salah satu jenis sengketa yang dapat muncul dalam penyelenggaraan Pilkada langsung adalah sengketa hasil Pilkada langsung. Sengketa hasil Pilkada langsung dapat diartikan sebagai sengketa yang muncul akibat yang ditetapkannya hasil Pilkada langsung oleh penyelenggara Pilkada langsung. Secara tekstual, sengketa hasil Pilkada langsung sebenarnya hanya bersifat kuantitatif yakni terkait dengan kekeliruan perhitungan atas hasil Pilkada langsung. Akan tetapi, dalam perkembangannya ditemukan bahwa sengketa hasil tidak hanya berupa sengketa kuantitatif, namun terkait juga dengan sengketa kualitatif, dimana proses Pilkada langsung yang mempengaruhi hasil dapat diuji.

Sengketa hasil pilkada langsung tersebut harus diselesaikan sesuai dengan hukum (due process of law). Hal tersebut sesuai dengan Pasal 1 ayat (3) UUD NRI Tahun 1945 yang menentukan bahwa "Indonesia adalah negara hukum". Karenanya, sebagai sebuah negara hukum, maka sengketa hasil Pilkada langsung harus diselesaikan melalui lembaga dan menurut tata cara yang telah ditentukan oleh hukum. Selain itu, sengketa hasil Pilkada langsung harus diselesaikan secara melembaga dan damai, sehingga tidak mengurangi legitimasi penyelenggaraan Pilkada langsung. Hal tersebut sesuai dengan nilai-nilai positif dan unsur-unsur universal dari demokrasi sebagai landasan penyelenggaraan Pilkada langsung, yakni adanya penyelesaian perselisihan dengan damai dan melembaga. ${ }^{15}$

Dengan adanya penyelesaian sengketa hasil Pilkada langsung yang demokratis, due process of law dan melembaga, maka akan mencegah terjadinya konflik sosial di tengah-tengah masyarakat. Penyelesaian sengketa hasil Pilkada langsung tersebut dapat memberikan

\footnotetext{
13 I Gde Panca Astawa, "Hak Angket dalam Sistem Ketatanegaraan Indonesia Menurut UUD 1945", (Bandung: Disertasi Doktor PPS Universitas Padjajaran, 200o), hlm. 84

14 Robert A Dahl dalam Yusak Elisa Reba, Op.cit.hlm. 71

15 Henry B. Mayo dalam Taufiqurrohman Syahuri, Putusan Mahkamah Konstitusi Tentang Perselisihan Hasil Penghitungan Suara Pemilihan Umum Berdasarkan Undang-Undang No. 24 Tahun 2003, (Bengkulu: Jurnal Konstitusi, PKK-FH, Universitas Bengkulu, Vol. II No.1 Juni 2009), hlm. 10
} 
Jurnal Magister Hukum Program Pascasarjana Universitas HKBP Nommensen

Volume o1 Nomor o1 Juli 2020 Halaman. 139-152

e-ISSN: 2723-164X p-ISSN: 2722-9858

http://ejournal.uhn.ac.id/index.php/opinion

kepercayaan kepada rakyat, bahwa suara yang mereka salurkan melalui Pilkada langsung tidak dicurangi oleh siapapun. Selain itu, penyelesaian sengketa hasil Pilkada langsung bertujuan untuk tetap menjaga suara rakyat secara konsisten demi tegaknya kedaulatan rakyat melalui Pilkada langsung yang demokratis.

Terkait dengan hal tersebut, maka penyelesaian sengketa hasil Pilkada langsung telah dikenal semenjak diadopsinya Pilkada langsung di dalam Undang-Undang Nomor 32 Tahun 2004. Selanjutnya Undang-Undang Nomor 32 Tahun 2004 tersebut memberikan kewenangan kepada Mahkamah Agung untuk menyelesaikan sengketa hasil Pilkada. Hal tersebut ditentukan di dalam Pasal 106 Undang-Undang Nomor 32 Tahun 2004 yang menentukan bahwa:

(1) Keberatan terhadap penetapan hasil pemilihan kepala daerah dan wakil kepala daerah hanya dapat diajukan oleh pasangan calon kepada Mahkamah Agung dalam waktu paling lambat 3 (tiga) hari setelah penetapan hasil pemilihan kepala daerah dan wakil kepala daerah.

(2)Keberatan sebagaimana dimaksud pada ayat (1) hanya berkenaan dengan hasil penghitungan suara yang mempengaruhi terpilihnya pasangan calon.

(3) Pengajuan keberatan kepada Mahkamah Agung sebagaimana dimaksud, pada ayat (1) disampaikan kepada pengadilan tinggi untuk pemilihan kepala daerah dan wakil kepala daerah provinsi dan kepada pengadilan negeri untuk pemilihan kepala daerah dan wakil kepala daerah kabupaten/kota.

Dengan dasar tersebut, Mahkamah Agung semenjak tahun 2005 menyelesaikan sengketa hasil Pilkada langsung. Namun, terminologi Pilkada langsung tersebut berubah menjadi Pemilihan Umum Kepala Daerah (Pemilukada) melalui Undang- Undang Nomor 22 Tahun 2007 tentang Penyelenggaraan Pemilihan Umum. Pasal 1 angka 4 Undang-Undang Nomor 22 Tahun 2007, menentukan bahwa: "Pemilu kepala daerah dan wakil kepala daerah adalah pemilu untuk memilih kepala daerah dan wakil kepala daerah secara langsung dalam Negara Kesatuan Republik Indonesia berdasarkan Pancasila dan Undang-Undang Dasar Negara Republik Indonesia Tahun 1945". Perubahan tersebut pada dasarnya bermula sejak Putusan Mahkamah Konstitusi Nomor 072-73/PUU-II/2004, tanggal 22 Maret 2005. Dalam putusan tersebut, ratio decidendi Mahkamah Konstitusi menyatakan bahwa: "Sebagai akibat (konsekuensi) logis dari pendapat Para Pemohon yang menyatakan bahwa Pilkada langsung adalah Pemilu sebagaimana dimaksud dalam Pasal 22E UUD 1945 yang dijabarkan dalam UU Nomor 12 Tahun 2003, maka perselisihan mengenai hasil pemilu, menurut Para Pemohon, harus diputus oleh Mahkamah Konstitusi. Tentang permohonan Para Pemohon untuk menyatakan Pasal 106 ayat (1) sampai dengan ayat (7) sebagai bertentangan dengan UUD NRI 1945, Mahkamah berpendapat bahwa secara konstitusional, pembuat undang-undang dapat saja memastikan bahwa Pilkada langsung itu merupakan perluasan pengertian Pemilu sebagaimana dimaksud dalam Pasal 22E UUD 1945 sehingga karena itu, perselisihan mengenai hasilnya menjadi bagian dari kewenangan Mahkamah Konstitusi dengan ketentuan Pasal 24C ayat (1) UUD $1945 \cdot{ }^{16}$ Namun pembentuk undang-undang juga dapat menentukan bahwa Pilkada langsung itu bukan Pemilu dalam arti formal yang disebut dalam Pasal 22E UUD 1945 sehingga perselisihan hasilnya ditentukan sebagai tambahan kewenangan Mahkamah Agung sebagaimana dimungkinkan Pasal 24A ayat (1) UUD 1945 yang berbunyi, "Mahkamah Agung berwenang mengadili pada tingkat kasasi, menguji peraturan perundang-undangan di bawah undang- undang terhadap undang-undang, dan mempunyai wewenang lainnya yang diberikan oleh undang-undang".

\footnotetext{
${ }^{16}$ Janpatar Simamora. "Problematika Penyelesaian Sengketa Kewenangan Lembaga Negara Oleh Mahkamah Konstitusi." Jurnal Mimbar Hukum Fakultas Hukum Universitas Gadjah Mada, Vol. 28, No. 1 (2016): 77-92.
} 
Jurnal Magister Hukum Program Pascasarjana Universitas HKBP Nommensen

Volume or Nomor o1 Juli 2020 Halaman. 139-152 e-ISSN: 2723-164X p-ISSN: 2722-9858

http://ejournal.uhn.ac.id/index.php/opinion

Jadi, dalam ratio decidendi putusan tersebut, Mahkamah Konstitusi sebenarnya memberikan ruang kepada pembentuk undang-undang untuk dapat memperluas makna Pemilu yang terdapat dalam ketentuan Pasal 22E UUD NRI 1945. Namun demikian, pada hakikatnya perluasan makna Pilkada menjadi Pemilukada bertentangan dengan Pasal 22E UUD NRI Tahun 1945. Karenanya, perubahan tersebut bertentangan tentang ketentuan Pasal 37 UUD NRI Tahun 1945, karena tidak melalui prosedur formal yang telah ditentukan.

Terkait dengan hal tersebut, Yusak Elisa Reba menyatakan bahwa Pasal 18 ayat (4) UUD NRI 1945 tidak secara tegas mengkategorikan pemilukada sebagai rezim pemilu, karena Kepala daerah dan wakil kepala daerah walaupun memegang jabatan selama lima tahun, namun dari aspek waktu masa jabatan tidak sama antara Bupati atau Gubernur di seluruh Indonesia dan pemilihan terhadap kepala daerah berkarakter lokal karena tidak mengikutsertakan wilayah lain di Indonesia. ${ }^{17}$ Namun, Widodo Ekatjahyana menyatakan bahwa, melalui konvensi ketatanegaraan tersebut, ketentuan Pasal 22E ayat (2) UUD 1945 telah mengalami perubahan yakni dengan cara memperluas pengertian pemilu, sehingga Pemilukada masuk menjadi rezim pemilu. $^{18}$

Perubahan terminologi tersebut membawa perubahan mendasar atas lembaga yang berwenang untu menyelesaikan sengketa hasil Pilkada langsung, yakni dari Magkamah Agung ke Mahkamah Konstitusi. Perpindahan tersebut didasarkan pada adanya kewenangan Mahkamah Konstitusi untuk menyelesaikan sengketa hasil pemilihan umum sebagaimana ditentukan di dalam Pasal 24C ayat (1) UUD NRI Tahun 1945 yang menetapkan bahwa "Mahkamah Konstitusi berwenang mengadili pada tingkat pertama dan terakhir yang putusannya bersifat final untuk dan memutus perselisihan tentang hasil pemilihan umum". Atas dasar ketentuan tersebut, maka berdasarkan Pasal 236C Undang-Undang Nomor 12 Tahun 2008 ditentukan bahwa kewenangan Mahkamah Agung dalam menyelesaikan hasil Pilkada langsung tersebut dialihkan menjadi kewenangan Mahkamah Konstutusi. Pasal 236C UndangUndang Nomor 12 Tahun 2008 menentukan: "Penanganan sengketa hasil perhitungan suara pemilihan kepala daerah dan wakil kepala daerah oleh Mahkamah Agung dialihkan kepada Mahkamah Konstitusi paling lama 18 (delapan bulan) sejak undang-undang ini diundangkan".

Peralihan kewenangan penyelesaian sengketa hasil Pilkada langsung telah menimbulkan perdebatan pro dan kontra di kalangan ahli hukum tata negara. Hal tersebut mengingat bahwa ketentuan Pasal 24C UUD NRI Tahun 1945 dan Pasal 10 Undang-Undang Nomor 24 Tahun 2003 hanya memberikan kewenangan kepada Mahkamah Konstitusi untuk menyelesaikan sengketa hasil Pemilu yang secara gramatikal dan original intent adalah pemilihan umum yang ditentukan di dalam Pasal 22E ayat (2) UUD NRI Tahun 1945. Oleh karenanya, banyak ahli menyatakan bahwa pengalihan kewenangan penyelesaian sengketa hasil Pilkada langsung ke Mahkamah Konstitusi adalah inkonstitusional.

Di isi yang lain, sebagian ahli hukum tata negara juga menyatakan bahwa peralihan kewenangan tersebut merupakan konstitusional dan merupakan perubahan yang sangat penting dalam sistem ketatanegaraan Indonesia. Walaupun timbul perdebatan secara akademis, Mahkamah Konstitusi tetap melaksanakan kewenangan yang diberikan oleh Pasal 236C Undang-Undang Nomor 12 Tahun 2008 tersebut. Di sisi yang lain, Undang-Undang Nomor 48 Tahun 2009 juga memberikan dasar hukum bagi kewenangan Mahkamah Konstitusi

\footnotetext{
${ }^{17}$ Yusak Elisa Reba, Op.Cit., hlm. 67

18 Widodo Ekatjahyana, Putusan Mahkamah Konstitusi Tentang Penyelesaian Perselisihan Hasil Pemilihan Gubernur Jawa Timur Putaran Kedua Tahun 2008 dan Implikasi Hukumnya, (Jambi: Jurnal Konstitusi, PSKP-FH Universitas Jambi, Vol. II No. 1 Juni 2009), hlm. 90
} 
di dalam menyelesaikan sengkata hasil Pilkada langsung. Dengan demikian, dengan dasar tersebut Mahkamah Konstitusi untuk pertama kali menggunakan kewenangannya tersebut di dalam perkara perselisihan hasil sengketa hasil pemilukada Jawa Timur yang tetuang dalam putusan No. 41/PHPU-D-VI/2008.

Perdebatan pro kontra tersebut berakhir pada tahun 2013, dimana MK menyatakan bahwa MK tidak berwenang untuk mengadili sengketa hasil Pilkada langsung. Hal tersebut dituangkan dalam Putusan Mahkamah Konstitusi Nomor 97/PUU-XI/2013. Putusan Mahkamah Konstitusi Nomor 97/PUU-XI/2013 tersebut didasarkan pada ratio decidendi sebagai berikut:

a. Bahwa Pasal 236C UU 12/2008, dan Pasal 29 ayat (1) huruf e UU 48/2009 memberikan kewenangan kepada Mahkamah untuk mengadili perselisihan hasil Pemilukada, padahal dalam Pasal 22 E ayat (2)

b. Bahwa Pemilukada bukan termasuk dalam ruang lingkup pemilihan umum, sehingga penanganan perselisihannya bukanlah menjadi ruang lingkup Mahkamah. Hal tersebut telah menimbulkan ketidakpastian hukum dan menyalahi asas "lex superiori derogat legi inferiori", karena Pasal 22E ayat (2) UUD 1945 sebagai norma hukum yang lebih tinggi tidak memberikan kewajiban kepada norma yang lebih rendah untuk mengatur penyelesaian sengketa Pemilukada diberikan kepada Mahkamah; - Bahwa pemisahan pemilihan kepala daerah dalam konstitusi dapat dimaknai pemilihan kepala daerah bukanlah merupakan bagian dari pemilihan umum, karena secara jelas telah diatur dalam konstitusi penyelenggaraan pemilihan umum tidak termasuk pemilihan kepala daerah. Oleh karena itu, Pasal 236C UU 12/2008 telah menyalahi pengertian pemilihan umum yang telah ditentukan dalam UUD 1945 yang kemudian diakomodasi oleh Pasal 29 ayat (1) huruf e UU 48/2009 dengan memberikan ketentuan kewenangan lain dari Mahkamah Konstitusi;

c. Bahwa kewenangan dan kewajiban Mahkamah telah ditentukan secara limitatif oleh UUD 1945 sebagaimana diatur dalam Pasal 24C ayat (1) dan ayat (2) UUD 1945. Kewenangan Mahkamah tersebut meliputi mengadili pada tingkat pertama dan terakhir yang putusannya bersifat final untuk menguji Undang- Undang terhadap Undang-Undang Dasar, memutus sengketa kewenangan lembaga negara yang kewenangannya diberikan oleh Undang-Undang Dasar, ${ }^{19}$ memutus pembubaran partai politik, dan memutus perselisihan hasil pemilihan umum. Adapun kewajiban Mahkamah adalah memberikan putusan atas pendapat DPR mengenai dugaan pelanggaran hukum yang dilakukan oleh Presiden dan/atau Wakil Presiden menurut Undang-Undang Dasar. Berdasarkan ketentuan Pasal 24C ayat (6) UUD 1945, ketentuan lebih lanjut mengenai Mahkamah Konstitusi hanya dapat diatur dengan UndangUndang yaitu khusus mengenai pengangkatan dan pemberhentian Hakim Konstitusi, hukum acara serta ketentuan lainnya tentang Mahkamah Konstitusi. Dari segi original intent, penggunaan kata "dengan undang-undang" dalam Pasal $24 \mathrm{C}$ ayat (6) tersebut dimaksudkan bahwa harus diatur dengan Undang-Undang tersendiri. Adapun maksud frasa "ketentuan lainnya tentang Mahkamah Konstitusi" adalah ketentuan mengenai organisasi atau hal-hal yang terkait dengan pelaksanaan fungsi dan wewenang Mahkamah Konstitusi. Oleh karena itu, berdasarkan ketentuan Pasal 24C ayat (6) tersebut, dibentuklah UU MK yang dalam Pasal 10 menentukan kembali salah satu kewenangan Mahkamah Konstitusi adalah mengadili pada tingkat pertama dan terakhir yang putusannya bersifat final untuk memutus perselisihan hasil pemilihan umum;

d. Bahwa kewenangan Mahkamah Konstitusi untuk memutus perselisihan hasil pemilihan umum sebagaimana dimaksud dalam Pasal 24 C ayat UUD 1945, harus dikaitkan makna

\footnotetext{
${ }^{19}$ Ulasan mengenai hal ini dapat dilihat dalam buku Janpatar Simamora, Hukum Kelembagaan Negara, Yogyakarta: Capiya Publishing, 2016.
} 
pemilihan umum dalam Pasal 22E UUD 1945 yang secara khusus dengan mengatur mengenai pemilihan umum. Paling tidak terdapat empat prinsip mengenai pemilihan umum dalam Pasal 22 E UUD 1945, yaitu: i) Pemilihan umum dilaksanakan secara langsung, umum, bebas, rahasia, jujur dan adil setiap lima tahun sekali, ii) Pemilihan umum diselenggarakan untuk memilih anggota Dewan Perwakilan Rakyat (DPR), Dewan Perwakilan Daerah (DPD), Presiden dan Wakil Presiden, serta Dewan Perwakilan Rakyat Daerah (DPRD), iii) Peserta pemilihan umum untuk memilih anggota DPR dan DPRD adalah partai politik dan pemilihan umum untuk memilih anggota DPD adalah perseorangan, dan iv) Pemilihan umum diselenggarakan oleh suatu komisi pemilihan umum yang bersifat nasional, tetap dan mandiri. Berdasarkan ketentuan Pasal $22 E$ UUD 1945 tersebut, dengan menggunakan penafsiran sistematis dan original intent, yang dimaksud pemilihan umum menurut UUD 1945 adalah pemilihan yang dilaksanakan sekali dalam setiap lima tahun untuk memilih anggota DPR, DPD, Presiden dan Wakil Presiden, serta DPRD. Oleh karena itu, sudah tepat ketentuan Pasal 74 ayat (2) UU MK yang menegaskan bahwa perselisihan hasil pemilihan umum yang menjadi kewenangan Mahkamah yaitu perselisihan hasil pemilihan umum anggota DPR, DPRD, DPD, serta Presiden dan Wakil Presiden. Pasal 74 ayat (2) tersebut menentukan bahwa permohonan penyelesaian hasil pemilihan umum hanya dapat diajukan terhadap penetapan hasil pemilihan umum yang dilakukan secara nasional oleh Komisi Pemilihan Umum yang mempengaruhi: a. Terpilihnya calon anggota Dewan Perwakilan Daerah; b. Penentuan pasangan calon yang masuk pada putaran kedua pemilihan Presiden dan Wakil Presiden serta terpilihnya pasangan calon Presiden dan Wakil Presiden; c. Perolehan kursi partai politik peserta pemilihan umum di suatu daerah pemilihan;

e. Bahwa pada sisi lain, pemilihan kepala daerah tidak diatur dalam Pasal $22 E$ UUD 1945 akan tetapi diatur secara khusus dalam Pasal 18 ayat (4) UUD 1945 yang menyatakan, "Gubernur, Bupati, dan walikota masing-masing sebagai kepala pemerintah daerah provinsi, kabupaten, dan kota dipilih secara demokratis." Menurut Mahkamah, makna frasa "dipilih secara demokratis", baik menurut original intent maupun dalam berbagai putusan Mahkamah sebelumnya dapat dilakukan baik pemilihan secara langsung oleh rakyat maupun oleh DPRD. Lahirnya kata demokratis dalam Pasal 18 ayat (4) UUD 1945 pada saat dilakukan perubahan UUD 1945 terdapat adanya 2 (dua) pendapat yang berbeda mengenai cara pemilihan kepala daerah. Satu pendapat menghendaki pemilihan kepala daerah dilakukan secara langsung oleh rakyat maupun oleh DPRD sementara pendapat lain menghendaki tidak dilakukan secara langsung oleh rakyat. Latar belakang pemikiran lahirnya rumusan Pasal 18 ayat (4) UUD 1945 saat itu adalah sistem pemilihan Kepala Daerah yang akan diterapkan disesuaikan dengan perkembangan masyarakat dan kondisi di setiap daerah yang bersangkutan. Pembentuk Undang-Undang dapat merumuskan sistem pemilihan yang dikehendaki oleh masyarakat di dalam pemilihan Kepala Daerah sehingga masyarakat mempunyai pilihan apakah akan menerapkan sistem perwakilan yang dilakukan oleh DPRD atau melalui sistem pemilihan secara langsung oleh rakyat. Tujuannya adalah agar menyesuaikan dengan dinamika perkembangan bangsa untuk menentukan sistem demokrasi yang dikehendaki oleh rakyat. Hal ini merupakan opened legal policy dari pembentuk Undang- Undang dan juga terkait erat dengan penghormatan dan perlindungan konstitusi terhadap keragaman adat istiadat dan budaya masyarakat di berbagai daerah yang berbeda-beda. Ada daerah yang lebih cenderung untuk menerapkan sistem pemilihan tidak langsung oleh rakyat dan ada pula daerah yang cenderung dan lebih siap dengan sistem pemilihan langsung oleh rakyat. Baik sistem pemilihan secara langsung (Direct Democracy) maupun sistem pemilihan secara tidak langsung atau perwakilan (Indirect Democracy) sama-sama masuk kategori sistem yang demokratis. Berdasarkan dua pandangan itulah kemudian disepakati menggunakan kata 
demokratis dalam Pasal 18 ayat (4) UUD 1945. Oleh karena pemilihan kepala daerah diatur dalam Pasal 18 UUD 1945 yang masuk pada rezim pemerintahan daerah adalah tepat Undang- Undang Nomor 32 Tahun 2004 tentang Pemerintahan Daerah (UU 32/2004) mengatur juga mengenai pemilihan kepada daerah dan penyelesaian perselisihannya diajukan ke Mahkamah Agung. Walaupun Mahkamah tidak menutup kemungkinan pemilihan kepala daerah diatur dalam Undang-Undang tersendiri, tetapi pemilihan kepala daerah tidak masuk rezim pemilihan umum sebagaimana dimaksud Pasal $22 E$ UUD 1945. Pembentuk UndangUndang berwenang untuk menentukan apakah pemilihan kepala daerah dilakukan secara langsung oleh rakyat atau dipilih oleh DPRD atau model pemilihan lainnya yang demokratis. Jika berdasarkan kewenangannya, pembentuk Undang- Undang menentukan pemilihan kepala daerah dilakukan oleh DPRD maka tidak relevan kewenangan Mahkamah Agung atau Mahkamah Konstitusi untuk mengadili perselisihan hasil pemilihan kepala daerah. Hal itu membuktikan pula bahwa memang pemilihan kepala daerah itu bukanlah pemilihan umum sebagaimana dimaksud Pasal 22E UUD 1945. Demikian juga halnya walaupun pembentuk Undang-Undang menentukan bahwa pemilihan kepala daerah dilakukan secara langsung oleh rakyat, tidak serta merta penyelesaian perselisihan hasil pemilihan kepala daerah harus dilakukan oleh Mahkamah Konstitusi. Logika demikian semakin memperoleh alasan yang kuat ketika pemilihan kepala desa yang dilakukan secara langsung oleh rakyat tidak serta merta dimaknai sebagai pemilihan umum yang penyelesaian atas perselisihan hasilnya dilakukan oleh Mahkamah Konstitusi.

Berdasarkan ratio decidendi di atas, diktum putusan Mahkamah Konstitusi Nomor 97/PUU-XI/2013 menentukan bahwa pemberian kewenangan penyelesaian sengketa hasil Pilkada langsung kepada Mahkamah Konstitusi yang diberikan melalui ketentuan Pasal $263 \mathrm{C}$ Undang-Undang Nomor 12 Tahun 2008 dan Pasal 29 ayat (1) huruf e Undang-Undang Nomor 48 Tahun 2009 adalah inkonstitusional dan harus dicabut, karena bertentangan dengan Pasal 24C ayat (1) dan Pasal 22E ayat (2) UUD NRI Tahun 1945 serta tidak memiliki kekuatan Hukum yang mengikat. Berdasarkan diktum di atas, maka Mahkamah Konstitusi tidak lagi memiliki kewenangan untuk mengadili, memeriksa dan memutus sengketa hasil Pilkada langsung. Alasan utama putusan tersebut adalah karena Pilkada langsung tidak dapat dipersamakan dengan rezim Pemilu yang diatur di dalam Pasal 22E ayat (2) UUD NRI Tahun 1945, sehingga pemberian kewenangan penyelesaian sengketa hasil Pilkada langsung kepada Mahkamah Konstitusi adalah inkonstitusional danharus dicabut, karena bertentangan dengan Pasal $24 \mathrm{C}$ ayat (1) dan Pasal 22E ayat (2) UUD NRI Tahun 1945.

Dengan dasar putusan tersebut, Mahkamah Konstitusi memberikan keleluasaan kepada pembentuk UU untuk menentukan lembaga peradilan yang berwenang untuk menyelesaikan sengketa hasil Pilkada. Namun, diktum Nomor 2 Putusan MK Nomor 97/PUU-XI/2013 menentukan bahwa: "Mahkamah Konstitusi masih berwenang berwenang mengadili perselisihan hasil pemilhan umum kepala daerah selama belum ada undang-undang yang mengatur mengenai hal tersebut". Diktum tersebut bertujuan untuk mengisi kekosongan hukum, sehingga pembentuk undang-undang dituntut untuk segera menentukan lembaga peradilan apa yang berwenang untuk menyelesaikan sengketa hasil Pilkada langsung. Kewenangan Mahkamah Konstitusi tersebut hanya bersifat sementara dan merupakan win-win solution, walaupun masih menimbulkan perdebatan ketatanegaraan.

Pasca putusan MK Nomor 97/PUU-XI/2013 di atas, pembentuk UU (wetgever/ legislator) menetapkan Undang-Undang Nomor 1 Tahun 2015. Pasal 157 UU No. 1 Tahun 2015 menentukan bahwa "Dalam hal terjadi perselisihan penetapan perolehan suara hasil Pemilihan, peserta Pemilihan dapat mengajukan permohonan pembatalan penetapan hasil penghitungan perolehan suara oleh KPU Provinsi dan KPU Kabupaten/Kota kepada Pengadilan Tinggi yang ditunjuk oleh 
http://ejournal.uhn.ac.id/index.php/opinion

Mahkamah Agung". Artinya dari ketentuan tersebut, maka yang memiliki kewenangan untuk menyelesaikan sengketa hasil pilkada langsung adalah pengadilan tinggi yang ditunjuk oleh Mahkamah Agung. Namun demikian ketentuan Pasal 157 ayat (1) Undang-Undang Nomor Tahun 2015 tersebut tidak berlaku lama, karena pembentuk Undang-Undang (wetgever/legislator) menetapkan Undang-Undang Nomor 8 Tahun 2015. Perubahan undangundang tersebut juga membawa perubahan kepada lembaga peradilan mana yang berwenang untuk menyelesaikan sengketa hasil pilkada langsung.

Terkait dengan hal tersebut, Pasal 157 undang-undang tersebut mengatur mengenai lembaga peradilan mana yang berwenang untuk menyelesaikan sengketa hasil Pilkada. Pasal 157 Undang-Undang Nomor 8 Tahun 2015 menentukan bahwa:

(1) Perkara perselisihan hasil Pemilihan diperiksa dan diadili oleh Badan Peradilan Khusus.

(2) Badan peradilan khusus sebagaimana dimaksud pada ayat (1) dibentuk sebelum pelaksanaan Pemilihan serentak nasional.

(3) Perkara perselisihan penetapan perolehan suara hasil Pemilihan diperiksa dan diadili oleh Mahkamah Konstitusi sampai dibentuknya badan peradilan khusus.

(4) ...dst

Berdasarkan ketentuan tersebut, terjadi pengalihan mengenai lembaga peradilan yang berwenang untuk menyelesaikan hasil sengketa Pilkada langsung, dimana sengketa hasil Pilkada diselesaikan oleh Badan Peradilan Khusus. Namun demikian, badan peradilan khusus apa yang dimaksud, Pasal 157 Undang- Undang Nomor 8 Tahun 2015 tidak menentukan secara limitatif. Pasal 157 ayat (2) Undang-Undang Nomor 8 Tahun 2015 hanya menentukan bahwa badan peradilan khusus tersebut akan dibentuk sebelum pelaksanaan pilkada serentak nasional. Ketentuan tersebut merupakan perumusan yang kurang tepat mengingat Mahkamah Konstitusi sudah memutuskan dirinya tidak berwenang lagi untuk menyelesaikan sengketa hasil Pilkada langsung. Hal ini disebabkan ketentuan tersebut merupakan ketentuan yang menggantung mengingat ketentuan Pasal 201 ayat (7) Undang-Undang Nomor 8 Tahun 2015 menentukan bahwa pemilihan kepala daerah serantak serentak nasional akan dilaksanakan pada tahun 2027. Artinya, bahwa ketentuan tersebut secara substansif bertentangan dengan putusan Mahkamah Konstitusi yang memberikan kewenangan kepada pembentuk undangundang untuk menunjuk lembaga peradilan yang berwenang untuk menyelesaikan sengketa hasil pilkada langsung.

\section{Peran Mahkamah Konstitusi dan Urgensi Badan Peradilan Khusus dalam Menyelesaikan Sengketa Pilkada}

Akibat ketidakjelasan lembaga yang berwenang untuk menyelesaikan sengketa hasil pilkada langsung sebagaimana diatur dalam Pasal 157 Undang-Undang Nomor 8 Tahun 2015, maka untuk mengisi kekosongan hukum (recht vacum), Pasal 157 ayat (3) Undang-Undang Nomor 8 Tahun 2015 menentukan bahwa Mahkamah Konstitusi diberikan kewenangan untuk menyelesaikan sengketa hasil pilkada langsung sampai terbentuknya badan peradilan khusus yang mempunyai kompetensi untuk menyelesaikan sengketa hasil pilkada langsung. Ketentuan tersebut memang ditentukan dalam diktum nomor 2 putusan Mahkamah Konstitusi Nomor 97/PUU-XI/2013 yang menentukan bahwa: "Mahkamah Konstitusi masih berwenang berwenang mengadili perselisihan hasil pemilhan umum kepala daerah selama belum ada undang-undang yang mengatur mengenai hal tersebut".

Norma hukum yang ada dalam diktum nomor 2 putusan Mahkamah Konstitusi Nomor 97/PUU-XI/2013 dan Pasal 157 ayat (3) UU No. 8 Tahun 2015 terdapat beberapa kekurangan yang sangat mendasar, karena bertentangan dengan diktum nomor 1 putusan Mahkamah Konstitusi Nomor 97/PUU-XI/2013. Diktum nomor 1 putusan Mahkamah Konstitusi Nomor 
97/PUU-XI/2013 menentukan bahwa norma Pasal 236C Undang-Undang Nomor 12 Tahun 2008 dan norma Pasal 29 ayat (1) huruf e Undang-Undang Nomor 48 Tahun 2008 bertentangan dengan UUD NRI 1945 serta tidak mempunyai kekuatan hukum mengikat, sehingga Mahkamah Konstitusi tidak lagi memiliki kewenangan untuk menyelesaikan sengketa hasil pilkada langsung.

Sehubungan dengan itu, menjadi tidak logis apabila melalui Pasal 175 ayat (3) UndangUndang Nomor 8 Tahun 2015 memberikan kewenangan kepada Mahkamah Konstitusi untuk menyelesaikan sengketa hasil pilkada langsung. Walaupun hal tersebut sangat dimungkinkan oleh diktum nomor 2 putusan Mahkamah Konstitusi Nomor 97/PUU-XI/2013, namun seharusnya pembentuk undang-undang memahami bahwa diktum tersebut bersifat sementara. Karenanya, seharusnya dalam undang-undang tersebut ditentukan lembaga peradilan yang berwenang. Apabila menunggu sampai dibentuknya badan peradilan khusus, maka kewenangan MK yang diberikan melalui Pasal 157 ayat (3) Undang-Undang Nomor 8 Tahun 2015 tidak bersifat sementara, karena butuh waktu sampai tahun 2027. Hal tersebut tidak memberikan kepastian hukum di dalam praktek ketatanegaraan khususnya dalam penyelenggaraan pemerintahan daerah di Indonesia.

Sebagaimana telah dijelaskan di atas, bahwa lembaga yang memiliki kewenangan untuk menyelesaikan sengketa hasil pilkada langsung telah mengalami perubahan dan peralihan. Hal ini menurut penulis terjadi karena ketidakjelasan arah politik hukum dalam penyelesaian sengketa hasil pilkada langsung. Karenanya, penulis mengajukan beberapa alternatif hukum yang dapat dijadikan solusi untuk menentukan lembaga yang berwenang untuk menyelesaikan sengketa hasil pilkada langsung. Alternatif-alternatif kelembagaan yang berfungsi untuk menyelesaikan sengketa hasil pilkada langsung yang bersifat khusus atau dapat ditempatkan sebagai opsi kekhususan adalah Mahkamah Konstitusi atau Badan Peradilan Khusus.

Walaupun dalam putusan Mahkamah Konstitusi Nomor 97/PUU-XI/2013 ditentukan bahwa Mahkamah Konstitusi tidak lagi berwenang untuk menyelesaikan sengketa hasil pilkada langsung, karena Pasal Pasal 236C Undang-Undang Nomor 12 Tahun 2008 dan norma Pasal 29 ayat (1) huruf e Undang-Undang Nomor 48 Tahun 2008 bertentangan dengan Pasal 22E ayat (2) dan Pasal 24C ayat (1). Alasan utama Mahkamah Konstitusi dalam putusannya tersebut adalah bahwa Pilkada bukan merupakan rezim Pemilu, karenanya menyamakan Pilkada dengan Pemilu bertentangan dengan prinsip lex superior derogate legi inferiori. Mahkamah Konstitusi berpendapat bahwa berdasarkan Pasal 24C ayat (1) UUD NRI Tahun 1945 ditentukan bahwa Mahkamah Konstitusi hanya diberikan kewenangan secara limitatif untuk menyelesaikan sengketa hasil Pemilu, dimana terminologi Pemilu sudah ditentukan secara limitatif di dalam Pasal 22E ayat (2) UUD NRI Tahun 1945. Oleh karena itu, ketentuan Undang-Undang yang memberikan kewenangan kepada MK untuk menyelesaikan sengketa hasil Pilkada langsung bertentangan dengan UUD NRI Tahun 1945.

Jika Mahkamah Konstitusi tetap diberikan kewenangan untuk menyelesaikan sengketa hasil Pilkada langsung, maka seharusnya terlebih dahulu dilakukan perubahan atas ketentuan Pasal 22E ayat (2) dan Pasal 24C ayat (1) UUD NRI Tahun 1945. Artinya terminologi Pilkada harus terlebih dahulu disamakan dengan terminologi Pemilu. Namun demikian, perubahan tersebut sebaiknya dilakukan melalui tata cara perubahan UUD NRI Tahun 1945 yang diatur dalam Pasal 37 UUD NRI Tahun 1945 (formale amandement).

Mahkamah Konstitusi tetap mempunyai kekhususan untuk diajukan sebagai lembaga penyelesai sengketa (perselisihan) pilkada langsung, meskipun bersifat sementara, karena Mahkamah Konstitusi sudah berpengalaman dalam menanganinya. Aspek kekuatan akademisi dan praktisi yang menjadi latarbelakang hakim Mahkamah Konstitusi dan proses peradilan cepat yang selama ini bisa diimplementasikan Mahkamah Konstitusi, dapat dijadikan jaminan 
Jurnal Magister Hukum Program Pascasarjana Universitas HKBP Nommensen

Volume or Nomor o1 Juli 2020 Halaman. 139-152 e-ISSN: 2723-164X p-ISSN: 2722-9858

http://ejournal.uhn.ac.id/index.php/opinion

untuk menangani penyelesaian sengketa pilkada langsung, apalagi pilkada kali ini akan dilaksanakan secara serentak, sehingga membutuhkan hakim-hakim kapatibel untuk menanganinya.

Selain eksistensi MK tersebut, salah satu lembaga lain yang sudah lama diamanatkan atau diberi tempat secara khusus oleh UU adalah "Badan Peradilan Khusus". Memang Badan ini tidak secara langsung disebut secara yuridis (berdasarkan Undang-Undang Nomor 48 Tahun 2009) akan menangani sengketa pilkada langsung, akan tetapi bisa dibentuk untuk menjadi solusi yuridis atas problem yuridis tertentu di tengah masyarakat, diantaranya pilkada langsung.

Pasal 1 angka 8 Undang-Undang Nomor 48 Tahun 2009 menentukan bahwa "Pengadilan Khusus adalah pengadilan yang mempunyai kewenangan untuk memeriksa, mengadili dan memutus perkara tertentu yang hanya dapat dibentuk dalam salah satu lingkungan badan peradilan yang berada di bawah Mahkamah Agung yang diatur dalam undang-undang”. Lebih lanjut Pasal 27 ayat (1) Undang-Undang Nomor 48 Tahun 2009 menentukan bahwa "Pengadilan khusus hanya dapat dibentuk dalam salah satu lingkungan peradilan yang berada di bawah Mahkamah Agung sebagaimana dimaksud dalam Pasal 25”.

Undang-Undang Nomor 48 Tahun 2009 memberikan kewenangan kepada pembentuk undang-undang untuk membentuk badan peradilan khusus, termasuk badan peradilan khusus yang mempunyai kewenangan untuk menyelesaikan sengketa hasil Pilkada langsung. Badan peradilan khusus penyelesaian sengketa Pilkada tersebut harus dibentuk di bawah 4 (empat) badan peradilan yang ada. Oleh karena itu, badan peradilan khusus yang ditentukan dalam Pasal 157 ayat (1) Undang-Undang Nomor 8 Tahun 2015 sebaiknya dibentuk di bawah peradilan tata usaha negara, mengingat sengketa hasil Pilkada langsung merupakan sengketa administratif yang menilai keabsahan keputusan penyelenggara Pilkada langsung terkait hasil Pilkada langsung.

Kalau Badan Peradilan Khusus bisa dibentuk, tentu saja diantaranya dengan belajar pada paradigma dan sistem penyelesaian perselisihan pilkada langsung yang pernah ditangani MK, maka barangkali hal ini akan menjadi solusi terbaik untuk "mengurangi" beban Mahkamah Konstitusi, yang idelitasnya terfokus pada penanganan problem konstitusional yang menjadi kewenangan dan kewajiban Mahkamah Konstitusi (Pasal 23 C ayat (1) dan (2)

\section{D.Kesimpulan}

Lembaga penyelesaian sengketa hasil Pilkada langsung telah berubah-berubah, yakni dari Mahkamah Agung sesuai dengan Pasal 106 Undang-Undang Nomor 32 Tahun 2004 berpindah menjadi kewenangan Mahkamah Konstitusi sesuai dengan Pasal 236C UndangUndang Nomor 12 Tahun 2008. Namun demikian, melalui putusan Mahkamah Konstitusi Nomor 97/PUU-XI/2013 dinyatakan bahwa ketentuan Pasal 236C Undang-Undang Nomor 12 Tahun 2008 bertentangan dengan UUD NRI Tahun 1945, sehingga MK tidak berwenang lagi untuk menyelesaikan sengketa hasil Pilkada langsung. Merespon hal tersebut, pembentuk UU melalui Pasal 157 ayat (1) Undang-Undang Nomor 1 Tahun 2015 menyerahkan kewenangan tersebut kepada Pengadilan Tinggi dan kemudian dirubah melalui Pasal 157 ayat (1) UndangUndang Nomor 8 Tahun 2015 menjadi kewenangan badan peradilan khusus. Sebelum badan peradilan khusus tersebut terbentuk, Mahkamah Konstitusi masih tetap berwenang untuk menyelesaikan sengketa hasil Pilkada langsung sebagaimana ditentukan dalam diktum nomor 2 putusan MK Nomor 97/PUU-XI/2013 dan Pasal 157 ayat (3) Undang-Undang Nomor 8 Tahun 2015. Kewenangan Mahkamah Konstitusi tersebut merupakan kewenangan konstitusional yang bersifat sementara, dan pada hakikatnya bertentangan dengan substansi putusan Mahkamah Konstitusi itu sendiri. Karenanya, pembentuk Undang-Undang harus segera membentuk 
Jurnal Magister Hukum Program Pascasarjana Universitas HKBP Nommensen

Volume or Nomor o1 Juli 2020 Halaman. 139-152 e-ISSN: 2723-164X p-ISSN: 2722-9858

http://ejournal.uhn.ac.id/index.php/opinion

badan peradilan khusus yang mempunyai kewenangan untuk menyelesaikan sengketa hasil Pilkada langsung.

\section{Daftar Pustaka}

Astawa, I Gde Panca. 2000. Hak Angket dalam Sistem Ketatanegaraan Indonesia Menurut UUD 1945. Bandung: Disertasi Doktor PPS Universitas Padjajaran.

Black, Hanry Campbell. 1979. Black Law Dictionary. USA: ST. Paul Mint. West Pu-blishing Co.

Budiarjo, Miriam. 199o. Hak Asasi Manusia Dalam Dimensi Global. Jakarta: Jurnal Ilmu Politik, No. 10.

Ekatjahyana, Widodo. 2009. Putusan Mahkamah Konstitusi Tentang Penyelesaian Perselisihan Hasil Pemilihan Gubernur Jawa Timur Putaran Kedua Tahun 2008 dan Implikasi Hukumnya. Jambi: Jurnal Konstitusi, PSKP-FH Universitas Jambi, Vol. II No. 1.

Gie, The Liang. 1967. Pertumbuhan Pemerintahan Daerah di Negara Republik Indonesia. Yogyakarta: Liberty.

Hadjon, Philipus M. Hadjon. Sistem Pembagian Kekuasaan Negara (Analisis Hukum Tata Negara). Surabaya: Fakultas Hukum Universitas Airlangga.

Nugroho, Agus Wijayanto. 2009. Kewenangan Mahkamah Konstitusi Dalam Sengketa Pemilu Legislatif (Sebuah Pembelajaran Dalam Mewujudkan dan Menjaga Kedaulatan Rakyat). Banjarmasin: Jurnal Konstitusi, PKK-FH, Lambung Mangkurat, Vol. II No. 1.

Reba, Yusak Elisa Reba. 2009. Kompetensi Mahkamah Konstitusi Dalam Menyelesaikan Sengketa Hasil Pemilihan Umum Kepala Daerah. Papua: Jurnal Konstitusi, PSK-FH, Uncen, Vol. 1 No. 1.

Said, M. Mas'ud Said. 2005. Arah Baru Otonomi Daerah di Indonesia. Malang: UMM Press.

Simamora, Janpatar. "Menyongsong Rezim Pemilu Serentak", Jurnal Rechtsvinding, BPHN Jakarta, Vol. 3 No 1 (2014). Lihat juga Simamora, Janpatar. "Eksistensi Pemilukada Dalam Rangka Mewujudkan Pemerintahan Daerah yang Demokratis." Jurnal Mimbar Hukum Fakultas Hukum Universitas Gadjah Mada, Vol. 23, No. 1 (2011): 221-236.

Simamora, Janpatar. "Perlindungan Hak Memilih Sebagai Hak Konstitusional Warga Negara." Jurnal Yudisial, Vol. 6, No. 2 (2013): 123-142.

Simamora, Janpatar. "Problematika Penyelesaian Sengketa Kewenangan Lembaga Negara Oleh Mahkamah Konstitusi." Jurnal Mimbar Hukum Fakultas Hukum Universitas Gadjah Mada, Vol. 28, No. 1 (2016): 77-92.

Simamora, Janpatar. "Tafsir Makna Negara Hukum dalam Perspektif Undang-Undang Dasar Negara Republik Indonesia Tahun 1945." Jurnal Dinamika Hukum 14, No. 3 (2014): 547561.

Simamora, Janpatar. Hukum Kelembagaan Negara, Yogyakarta: Capiya Publishing, 2016.

Syahuri, Taufiqurrohman. 200o. Putusan Mahkamah Konstitusi Tentang Perselisihan Hasil Penghitungan Suara Pemilihan Umum Berdasarkan Undang-Undang No. 24 Tahun 2003. Bengkulu: Jurnal Konstitusi, PKK-FH, Universitas Bengkulu, Vol. II No.1.

Thaib, Dahlan. 1993. Implementasi Sistem Ketatanegaraan Menurut UUD 1945. Yogyakarta: Liberty. 